\section{Anteroposterior and Vertical Changes in Skeletal Class II Patients Treated With Modified Thurow Appliance}

\author{
Matheus Melo Pithon', Rogério Lacerda dos Santos², Gêisa Aiane de Morais \\ Sampaio $^{3}$, Izaura Helena Chaves de Meneses ${ }^{3}$, Raildo Silva Coqueiro ${ }^{4}$
}

\author{
'Department of Orthodontics, UESB \\ - State University of Southwest \\ Bahia, Jequié, BA, Brazil \\ ${ }^{2}$ Department of Orthodontics \\ and Pediatric Dentistry, UFCG - \\ Federal University of Campina \\ Grande, Patos, PB, Brazil \\ ${ }^{3}$ Postgraduate Program in Dentistry, \\ UFPB - Federal University of \\ Paraíba, João Pessoa, PB, Brazil \\ ${ }^{4}$ Department of Epidemiology, UESB \\ - State University of Southwest \\ Bahia, Jequié, BA, Brazil
}

Correspondence: Dr. Matheus Melo Pithon, Avenida Otávio Santos, 395, sl 705, Centro Odontomédico Dr. Altamirando da Costa Lima, Recreio, 45020-750 Vitória da Conquista, BA, Brasil. Tel:+55-77-9125-9025. e-mail: matheuspithon@gmail.com

\section{Introduction}

Class II malocclusion may be caused by bone dysplasia or by movement of the dental arch, or by a combination of skeletal and dental factors (1). Moreover, associated abnormalities in the activity of the orofacial musculature contribute to accentuate and perpetuate this malocclusion (2-3).

The period of mixed dentition is the most indicated stage for the treatment of this malocclusion (4-6), in which at least half of the children go through a growth spurt and a speed to a level of at least 50\% related to pubertal changes (7).

Among the orthopedic appliance that propose to redirect the growth of the maxillary complex (8), special mention is made of the Thurow (6) extraoral appliance (1975), coupled to a maxillary splint, which is capable of redirecting the maxilla spatially, in addition to providing improvements in the position of the teeth.

With the intention of adding favorable characteristics to these devices, modifications have been suggested over the years, such as the incorporation of an expander screw, changes in the extraoral traction and in the configuration of the acrylic that covers the teeth. However, up to now, no investigation has been made to evaluate the behavior of these devices, particularly with respect to patients with different anteroposterior positioning of the maxilla, considering that these devices are routinely used for the purpose of correcting maxillomandibular discrepancy, without worrying about the maxillary position in relation to the base of the skull. Therefore, the purpose of the present study was to fill this gap in the literature by evaluating the post-treatment anteroposterior and vertical alterations in skeletal Class II malocclusion with different maxillary patterns in patients treated with modified Thurow cervical traction appliance.

\section{Material and Methods Selection of Patients}

This work was approved by the Ethics Committee on Human Research of the State University of Southwest Bahia (CCS/UESB, CEP/No.CAAE:0154.0.454.000-11). The sample consisted of 45 patients (22 were boys and 23 girls) with a mean age of 9 years at pre-treatment (T1) and 9 years and 10 months at post-treatment (T2). From 90 digital teleradiographs that came from the same radiology center, lateral cephalograms were obtained and used for the evaluations at stages T1 and T2. To obtain the teleradiographs, the position of patients was standardized in 
dental occlusion and the Frankfurt horizontal plane parallel to the ground. The correction of the magnification factor of the images was performed considering the degree of magnification recorded for all radiographs, of $8 \%$.

The patients were selected for treatment at the dental clinic of the State University of South East Bahia (UESB) in accordance with the following inclusion criteria: presence of skeletal Class II, Division 1 with angle ANB > $4^{\circ}$, anteroposterior discrepancy of molar relation $<5 \mathrm{~mm}$ (relationship between the tip of the mesiobuccal cusp of the permanent maxillary first molar with buccal groove of the permanent mandibular first molar), angle SN.GoGn $\leq$ 35 , severity of dental discrepancy between the right and left sides compatible for linear and angular measurements, similar skeletal maturation (hand-wrist radiographic evaluation), mixed dentition, absence of open and cross bite, absence of caries, periodontal disease and early tooth losses. Exclusion criteria were: children with syndromes, motor limitation for use of the device or who did not use the appliance until the correction of molar relationship.

This study was comparative between stages $\mathrm{T} 1$ and $\mathrm{T} 2$, and between the maxillary pattern: retrusive (SNA < $\left.80^{\circ}\right)$, normal (SNA $=80^{\circ}-84^{\circ}$ ) or protrusive (SNA $>84^{\circ}$ ) maxilla ( $n=15$ patients for each pattern). All the patients were treated only with the modified Thurow appliance until a Class I relationship of the permanent first molars was obtained. Sample size was calculated considering the minimal difference between the means of treatments of 1 $\mathrm{mm}$ for any of the linear distances (Class II right or Class II left) and a standard deviation of $0.5 \mathrm{~mm}$. With a onesided significance level of 0.01 and a power of $95 \%$, and a minimum of 12 patients per group was required.
As the treatment protocol, the appliance was used before the eruption of the premolars, with cervical traction and use for 12-14 h per day, with a force of $500 \mathrm{gf}$ on each side, for the purpose of producing an orthopedic effect on the maxilla. The Thurow Appliance was used for a mean period of time of 10 months for correction of the molar relationship. The patients were attended in fortnightly appointments so that $1 / 4$ of a turn activation of the expander could be promoted, with a view to maintaining an adequate transverse relationship between the maxilla and mandible during skeletal maxillary movement, and monthly appointments for adjustments to the face bow, with the intention of maintaining an elevation from $10^{\circ}$ to $20^{\circ}$ to prevent excessive distal inclination of the molars.

\section{Orthodontic Appliance}

The design of the appliance used was based on the appliance described by Thurow (6) and has the following components: an occlusal self-polymerizing acrylic resin (OrtoCril, Pirassununga, SP, Brazil) baseplate that covers the entire palate until the contact of the occlusal surfaces of the primary molars and the permanent 1st molar with an expander screw (Morelli Ortodontia, Sorocaba, SP, Brazil) centralized in the palate at the level of the primary second molars (5), and Adams' cribs for retention on both upper first permanent molars. In addition to this, cervical traction (Morelli Ortodontia) was used for redirecting maxillary growth (Fig. $1 \mathrm{~A}, \mathrm{~B}$ ).

The extraoral face bow was folded upwards from the horizontal plane from $10^{\circ}$ to $20^{\circ}$ in relation to the intraoral arch, without undergoing shortening procedures, with the aim of retaining the appliance on the teeth and obtaining
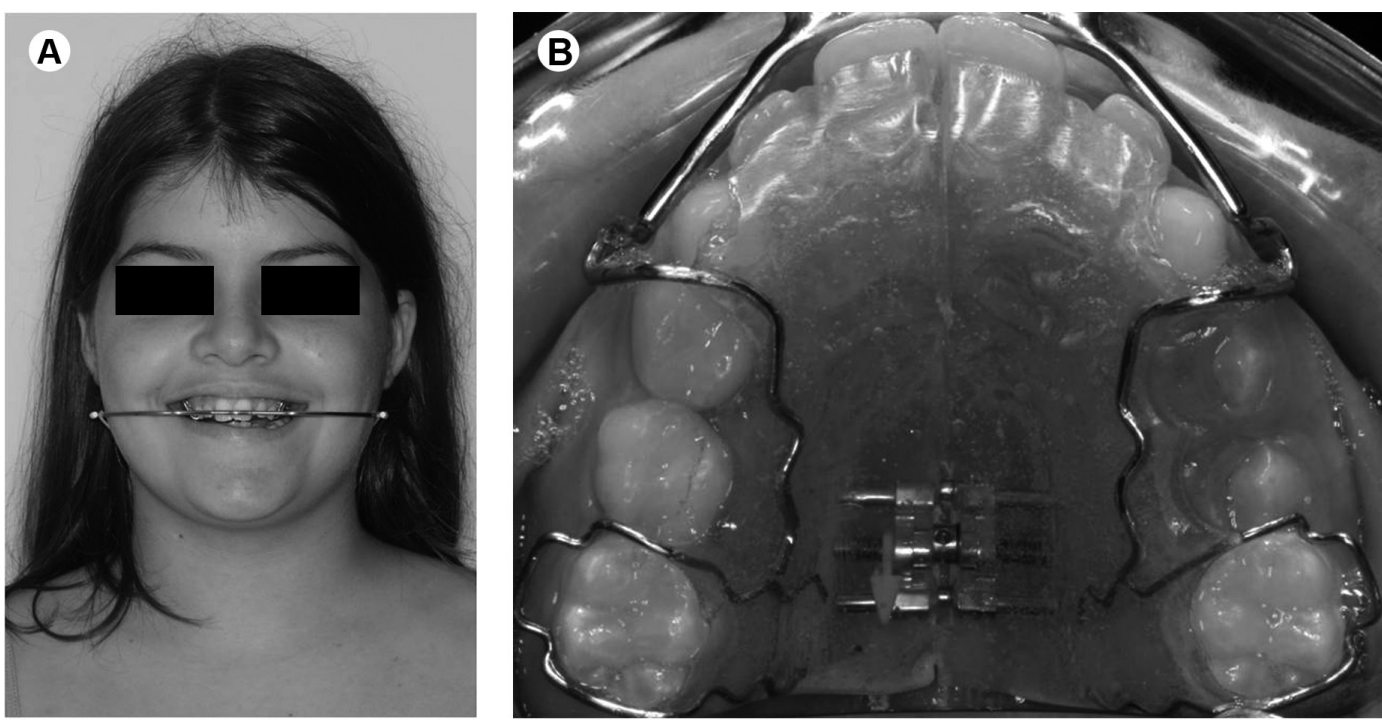

Figure 1. A: Frontal view of a patient with the modified Thurow appliance. B: Intraoral occlusal view of the upper arch. 
an angle close to $180^{\circ}$ between the point of application and direction of force, in order to provide anteroposterior action in maxillary growth without intrusion. The extremities of the extraoral bow were connected to an elastic ( 0.5 in $\times 1.5$ $\mathrm{mm}$ ), which was connected to a cervical cushion (Morelli Ortodontia). The force applied of an average of $500 \mathrm{gf}$, was calibrated with a dynamometer (Ohaus Corp., Florham Park, New Jersey, USA).

\section{Method Error}

In order to assess the method error and increase its reliability, 12 teleradiographs were randomly selected from stages $\mathrm{T} 1$ and $\mathrm{T} 2$. The radiographs were traced again by a single operator blinded to the groups, after a minimum period of 4 weeks from the initial tracing, according to Midtgard, Björk and Linder-Aronson (9).

The error was calculated in accordance with the formula proposed by Dahlberg and defended by Houston (10), and the paired t-test, or paired Wilcoxon test was performed, to compare the two time intervals with a level of significance of $5 \%$. The deviation values were below $\vec{s}$ the acceptable limits to assess the method error which is $1.5^{\circ}$ for the angular measurements and $1.0 \mathrm{~mm}$ for the linear measurements, in accordance with Houston's recommendations (10).

\section{Data Analysis}

For each parameter evaluated, descriptive statistical procedures were used, including mean and standard deviation. One-way analysis of variance (ANOVA) with Tukey's post-hoc test was used to determine the possible differences among the three groups of maxilla positions with regard to the mean values in Stages T1 and T2, and changes in the studied cephalometric parameters. In the cases in which there was no homogeneity, verified by the Levene test for equality of errors in variances, and normality of residues verified by the Shapiro-Wilk test, the Kruskal-Wallis test followed by the Mann-Whitney test for comparison between pairs, were also used. The level of significance adopted was $5 \%$. The data were tabulated and analyzed in the statistical program (BioEstat version 5.0, Belém, PA, Brazil).

\section{Results}

In stage T1 no statistical differences were found among the groups protrusive, normal and retrusive maxilla for the variables SN.GoGn, 1.NA, overjet, overbite and Class II discrepancy (right and left) ( $p>0.05$ ) (Table 1). The angular measurements SNA, SNB and ANB in the protrusive maxilla group were significantly greater than in the normal and retrusive maxilla groups $(p<0.01)$. However, there was no significant difference in the mean values of ANB between the normal and retrusive maxilla groups ( $p>0.05$ ).

In stage T2 no statistically significant differences were found among the groups protrusive, normal and retrusive maxilla for the variables ANB, SN.GoGn, 1.NA, overbite and Class II discrepancy (right and left) ( $p>0.05$ ) (Table 2). The angular measurements of SNA and SNB in the protrusive

Table 1. Mean values ( \pm standard deviation) of pre-treatment maxillary patterns (stage T1)

\begin{tabular}{|c|c|c|c|c|}
\hline Variable & $\begin{array}{l}\text { Protrusive maxilla } \\
\text { group }(\mathrm{n}=15)\end{array}$ & $\begin{array}{l}\text { Normal maxilla } \\
\text { group }(n=15)\end{array}$ & $\begin{array}{l}\text { Retrusive maxilla } \\
\text { group }(n=15)\end{array}$ & $p$ value \\
\hline SNA ( $\left.{ }^{\circ}\right)$ & $86.80 \pm 1.23^{\mathrm{a}}$ & $81.90 \pm 1.20^{\mathrm{b}}$ & $77.10 \pm 1.20^{c}$ & $<0.001^{*}$ \\
\hline SNB $\left(^{\circ}\right)$ & $79.60 \pm 1.26^{\mathrm{a}}$ & $77.10 \pm 1.37^{b}$ & $72.00 \pm 1.25^{c}$ & $<0.001^{*}$ \\
\hline ANB $\left({ }^{\circ}\right)$ & $7.20 \pm 0.92^{\mathrm{a}}$ & $4.80 \pm 0.80^{\mathrm{b}}$ & $5.10 \pm 0.88^{b}$ & $0.002^{+}$ \\
\hline SN.GoGn $\left(^{\circ}\right)$ & $34.10 \pm 0.87$ & $33.70 \pm 0.82$ & $33.20 \pm 1.32$ & $0.267^{\dagger}$ \\
\hline 1.NA $\left(^{\circ}\right)$ & $30.50 \pm 2.22$ & $30.30 \pm 1.34$ & $29.90 \pm 1.53$ & $0.737^{*}$ \\
\hline Overjet (mm) & $6.70 \pm 1.42$ & $6.21 \pm 0.86$ & $6.70 \pm 1.42$ & $0.610^{*}$ \\
\hline Overbite (mm) & $5.80 \pm 0.79$ & $5.05 \pm 0.80$ & $5.80 \pm 0.79$ & $0.086^{+}$ \\
\hline Class 11 right $(\mathrm{mm})$ & $3.35 \pm 0.94$ & $3.50 \pm 0.88$ & $3.35 \pm 0.94$ & $0.916^{*}$ \\
\hline Class 11 left (mm) & $3.35 \pm 0.47$ & $3.50 \pm 0.88$ & $3.35 \pm 0.47$ & $1.000^{+}$ \\
\hline
\end{tabular}

*One-way ANOVA; ${ }^{\dagger}$ Kruskal-Wallis Test. ${ }^{a, b, c}$ Different letters indicate statistically significant difference (Tukey's or Mann-Whitney test).

Table 2. Mean values ( \pm standard deviation) of post-treatment maxillary patterns (stage T2)

\begin{tabular}{|c|c|c|c|c|}
\hline Variable & $\begin{array}{l}\text { Protrusive maxilla } \\
\text { group }(\mathrm{n}=15)\end{array}$ & $\begin{array}{l}\text { Normal maxilla } \\
\text { group }(\mathrm{n}=15)\end{array}$ & $\begin{array}{l}\text { Retrusive maxilla } \\
\text { group }(\mathrm{n}=15)\end{array}$ & $p$ value \\
\hline SNA ( $\left.{ }^{\circ}\right)$ & $83.30 \pm 1.49^{a}$ & $80.60 \pm 0.60^{\mathrm{b}}$ & $75.80 \pm 1.14^{c}$ & $<0.001^{+}$ \\
\hline SNB $\left(^{\circ}\right)$ & $80.00 \pm 0.94^{\mathrm{a}}$ & $77.40 \pm 1.35^{\mathrm{b}}$ & $72.20 \pm 1.23^{c}$ & $<0.001^{+}$ \\
\hline ANB $\left({ }^{\circ}\right)$ & $3.30 \pm 1.16$ & $3.20 \pm 1.55$ & $3.60 \pm 1.07$ & $0.769^{*}$ \\
\hline SN.GoGn () & $33.70 \pm 1.49$ & $33.45 \pm 0.96$ & $33.00 \pm 1.15$ & $0.442^{*}$ \\
\hline 1.NA $\left({ }^{\circ}\right)$ & $21.80 \pm 2.57$ & $21.40 \pm 2.07$ & $20.90 \pm 1.29$ & $0.620^{*}$ \\
\hline Overjet (mm) & $2.75 \pm 0.68^{\mathrm{a}}$ & $2.80 \pm 0.35^{\mathrm{a}}$ & $2.15 \pm 0.41^{\mathrm{b}}$ & $0.013^{\dagger}$ \\
\hline Overbite (mm) & $1.95 \pm 0.50$ & $1.85 \pm 0.53$ & $2.25 \pm 0.72$ & $0.303^{*}$ \\
\hline Class 11 right $(\mathrm{mm})$ & $0.00 \pm 0.00$ & $0.00 \pm 0.00$ & $0.00 \pm 0.00$ & $1.000^{+}$ \\
\hline Class 11 left (mm) & $0.00 \pm 0.00$ & $0.00 \pm 0.00$ & $0.00 \pm 0.00$ & $1.000^{+}$ \\
\hline
\end{tabular}

*One-way ANOVA; ${ }^{\dagger}$ Kruskal-Wallis Test. a,b,c Different letters indicate statistically significant difference (Tukey's or Mann-Whitney test). 
maxilla group were significantly greater than in the normal and retrusive maxilla groups $(p<0.01)$. The linear values of overjet of the protrusive and normal maxilla groups were statistically higher than those in the retrusive maxilla group $(p=0.013)$. However, there was no significant difference in the mean values of overjet between the protrusive and normal maxilla groups ( $p>0.05$ ).

As regards the changes obtained from stage $\mathrm{T} 1$ to $\mathrm{T} 2$, no statistically significant differences were found among the groups protrusive, normal and retrusive maxilla for the variables SNB, SN.GoGn, 1.NA, overjet, overbite and Class II discrepancy (right and left) ( $p>0.05$ ) (Table 3). Angular measurements SNA and ANB in the protrusive maxilla group were significantly greater than those in the normal and retrusive maxilla groups $(p<0.01)$. However, in the normal maxilla group these values did not differ from those of the retrusive maxilla group ( $p>0.05$ ).

\section{Discussion}

The Thurow appliance is an alternative in the treatment of skeletal Class II malocclusions (5-6) and orthopedic forces (11) from 400 to $800 \mathrm{gf}$ are commonly used for the correction of this malocclusion (4-6,12-13). Stuani et al. (5) and Sadowsky (14) have reported that when the treatment is started early at the stage of highest pubertal growth, one has the opportunity to take maximum advantage of the growth of the bony bases, and one is able to count on greater cooperation from the patient in the use of extraoral appliances (15), than when the patient reaches adolescence (6).

In the present study, an orthopedic force of $500 \mathrm{gf}$ was used intermittently for 12-14 h/day. Thurow (6) recommended the use of the extraoral appliance for $12 \mathrm{~h}$

Table 3. Difference between pre-treatment and post-treatment maxillary patterns (stages $\mathrm{T} 1$ and T2) expressed as mean values \pm standard deviation

\begin{tabular}{|c|c|c|c|c|}
\hline Variable & $\begin{array}{l}\text { Protrusive maxilla } \\
\text { group }(\mathrm{n}=15)\end{array}$ & $\begin{array}{l}\text { Normal maxilla } \\
\text { group }(\mathrm{n}=15)\end{array}$ & $\begin{array}{l}\text { Retrusive maxilla } \\
\text { group }(\mathrm{n}=15)\end{array}$ & $\begin{array}{c}\mathrm{p} \\
\text { value }\end{array}$ \\
\hline SNA ( $\left.{ }^{\circ}\right)$ & $-3.50 \pm 1.35^{a}$ & $-1.30 \pm 1.42^{\mathrm{b}}$ & $-1.30 \pm 0.67^{b}$ & $0.001^{+}$ \\
\hline SNB $\left(^{\circ}\right)$ & $0.40 \pm 0.84$ & $0.30 \pm 0.67$ & $0.20 \pm 0.42$ & $0.976^{+}$ \\
\hline ANB $\left({ }^{\circ}\right)$ & $-3.90 \pm 1.73^{a}$ & $-1.60 \pm 1.71^{b}$ & $-1.50 \pm 0.71^{b}$ & $0.002^{+}$ \\
\hline SN.GoGn $\left(^{\circ}\right)$ & $-0.40 \pm 0.97$ & $-0.25 \pm 0.42$ & $-0.20 \pm 0.42$ & $0.912^{+}$ \\
\hline 1.NA $\left(^{\circ}\right)$ & $-8.70 \pm 1.89$ & $-8.90 \pm 3.00$ & $-9.00 \pm 1.83$ & $0.806^{+}$ \\
\hline Overjet (mm) & $-3.95 \pm 1.23$ & $-3.41 \pm 0.85$ & $-4.55 \pm 1.55$ & $0.142^{*}$ \\
\hline Overbite (mm) & $-3.85 \pm 1.06$ & $-3.20 \pm 1.21$ & $-3.55 \pm 1.07$ & $0.436^{*}$ \\
\hline Class 11 right $(\mathrm{mm})$ & $-3.35 \pm 0.94$ & $-3.50 \pm 0.88$ & $-3.35 \pm 0.94$ & $0.916^{*}$ \\
\hline Class 11 left (mm) & $-3.35 \pm 0.47$ & $-3.50 \pm 0.88$ & $-3.35 \pm 0.47$ & $1.000^{+}$ \\
\hline
\end{tabular}

*One-way ANOVA; ${ }^{\dagger}$ Kruskal-Wallis Test. ${ }^{\text {ab, }, \mathrm{c}}$ Different letters indicate statistically significant difference (Tukey or Mann-Whitney test). per day, and justified this due to the fact that the growth spurts occurred during sleep. Few studies (5-6) about the Thurow appliance are mentioned in the literature $(4,12-$ $14,16-18)$, which encouraged to the execution of this study.

The results of this study demonstrated that the variation in angle SNA from T1 to T2 was the main responsible for the treatment correction due the distalization of the maxilla achieved, and the variation in angle SNB had little influence on the correction of skeletal Class II.

In addition, the favorable alterations observed in angles SNB and SN.GoGn from T1 to T2 may have been favored by the slow expansion of the maxilla promoted by activation of the expander screw; and similar results have been observed in studies $(4,19)$ of extraoral cervical traction appliances and Thurow (5). The expanded maxillary arch favors the releasing the mandible to move anteriorly, which associated with mandibular growth, helps in correction of skeletal Class II $(4,20)$.

In this study, with the use of the cervical Thurow appliance, it may be observed that the mandible did not undergo significant rotation in the clockwise direction from $\mathrm{T} 1$ to $\mathrm{T} 2$, and anterior growth of the mandible favored correction of the anteroposterior dysplasia, confirmed by SN.GoGn and SNB in T2, respectively.

Due to the potential risk of extrusion of the maxillary molars with the use of modified cervical Thurow appliance, the extraoral long bow was maintained in all the appliances, and this may have favored less extrusion of the maxillary molars, which corroborates with studies that used a long bow in extraoral appliances $(4,19)$, and observed little maxillary molar extrusion without opening of the angle of the mandibular plane, and without excessive distal inclination of the molars (16), even in dolichocephalous patients (19). This procedure was adopted to control the mandibular plane because the angle SN.GoGn $<35$ of the patients in $\mathrm{T} 1$, considered a little above the standard mean $\left(32^{\circ}\right)$. On the other hand, the mandibular growth observed in this clinical study was similar to that demonstrated in patients with a normal facial pattern and with horizontal growth (21), which has the capacity to maintain the angle of the mandibular plane constant from $\mathrm{T} 1$ to $\mathrm{T} 2$, compensating the extrusion and/or alveolar growth in the molar region (22), from the significant increase in the height of the mandibular ramus (23).

In this study, the modified Thurow appliance had a greater effect on the protrusive maxilla compared with the normal and retrusive maxilla, confirmed 
by the SNA, which favored greater correction of the relationship between the bony bases demonstrated by ANB in T2. Control of the maxilla could be observed both in the vertical and anteroposterior direction, with the use of cervical traction and directioning of the force, irrespective of the maxillary pattern.

After the use of the modified Thurow appliance (24) a second stage with a fixed appliance is usually necessary, but it would be faster and easier, which makes this type of treatment extremely attractive, being a type of extraoral appliance, which could be used in patients different (25).

It may be concluded that, the modified Thurow appliance combined with cervical traction was efficient for the correction of skeletal Class II irrespective of the maxillary pattern. Patients with maxillary protrusion pattern had the greatest effect of correction with Thurow. The mandible had no significant rotation during treatment.

\section{Resumo}

0 objetivo deste estudo foi avaliar as alterações verticais e ântero-posterior pós-tratamento da maloclusão Classe Il esquelética com diferentes padrões maxilar de pacientes tratados com aparelho Thurow modificado. Quarenta e cinco pacientes (22 meninas e 23 meninos) com Classe II esquelética e ângulo SN.GoGn $\leq 35$ e diferente padrão maxilar $(n=15)$,sendo: maxila $\vec{\approx}$ retrusiva $\left(\mathrm{SNA}<80^{\circ}\right)$, normal $\left(\mathrm{SNA}=80^{\circ}-84^{\circ}\right.$ ) ou protrusiva $\left(\mathrm{SNA}>84^{\circ}\right)$ e ¿ idade média de 9 anos no pré-tratamento (T1) e 9 anos e 10 meses no pós-tratamento (T2), foram tratados com aparelho Thurow modificado de tração cervical com parafuso expansor e arco facial externo com dobra de $10^{\circ}$ a $20^{\circ}$ em relação ao arco interno. Foi empregado a força de 500 gf e uso de 12 a 14 h/dia, com ajustes quinzenais. Análise de variância ANOVA seguido pelo teste post-hoc de Tukey e o teste de Kruskal-Wallis seguido por Mann-Whitney foram empregados $(p<0.05)$. Nas mudanças obtidas da fase T1 para T2, não foram encontradas diferenças estatísticas entre os grupos maxila protusiva, normal e retrusiva para as variáveis SNB, SN.GoGn, 1.NA, overjet, overbite e discrepância de classe II (direita e esquerda) ( $p>0.05$ ). As medidas angulares SNA e ANB no grupo maxila protusiva foi significativamente maior do que nos grupos maxila normal e retrusiva $(p<0.01)$. Entretanto, esses valores no grupo maxila normal não diferiram do grupo maxila retrusiva ( $p>0.05)$. Dentro dos limites do estudo, pode-se concluir que o aparelho de Thurow modificado de tração cervical foi eficiente na correção da Classe II esquelética independente do padrão maxilar. A mandibula não teve rotação significativa durante o tratamento.

\section{References}

1. Moyers RE, Riolo ML, Guire KE, Wainright RL, Bookstein FL. Differential diagnosis of class II malocclusions. Part 1. Facial types associated with class II malocclusions. Am J Orthod Dentofacial Orthop 1980;78:47794.

2. Ballard CF. An orthodontic review of occlusions in relation to periodontal problems. Dent Pract 1953;3:311-320.
3. Pithon $M M$, Santos RL, Ribeiro DLR, Santana CL, Pedroza JPC. Soft tissue thickness in young north eastern Brazilian individuals with different skeletal classes. J Forensic Leg Med 2014;22:115-120.

4. Lima Filho RM, Lima AL, de Oliveira Ruellas AC. Mandibular changes in skeletal class II patients treated with Kloehn cervical headgear. Am J Orthod Dentofacial Orthop 2003;124:83-90.

5. Stuani MB, Stuani AS. Modified Thurow appliance: a clinical alternative for correcting skeletal open bite. Am J Orthod Dentofacial Orthop 2005;128:118-25.

6. Thurow RC. Craniomaxillary orthopedic correction with en masse dental control. Am J Orthod Dentofacial Orthop 1975;68:601-24.

7. Linder-Aronson S, Woodside DG, Daigle DJ. A longitudinal study of the growth in length of the maxilla in boys between ages 6-20 years. Trans Eur Orthod Soc 1975;82:169-79.

8. Bernstein L, Ulbrich RW, Gianelly AA. Orthopedics versus orthodontics in class II treatment: an implant study. Am J Orthod Dentofacial Orthop 1977;72:549-59

9. Midtgard J, Bjork G, Linder-Aronson S. Reproducibility of cephalometric landmarks and errors of measurements of cephalometric cranial distances. Angle Orthod 1974;44:56-61.

10. Houston WJ. The analysis of errors in orthodontic measurements. Am J Orthod Dentofacial Orthop 1983;83:382-390.

11. Sassouni V. Dentofacial orthopedics: a critical review. Am J Orthod Dentofacial Orthop 1972;61:255-269.

12. Armstrong MM. Controlling the magnitude, direction, and duration of extraoral force. Am J Orthod Dentofacial Orthop 1971;59:217-43.

13. Watson WG. A computerized appraisal of the high-pull face-bow. Am J Orthod Dentofacial Orthop 1972;62:561-579.

14. Sadowsky PL. Craniofacial growth and the timing of treatment. Am J Orthod Dentofacial Orthop 1998;113:19-23.

15. Matsumoto MAN, Romano FL, Ferreira JTL, Valério RA. Open bite: diagnosis, treatment and stability. Braz Dent J 2012; 23: 768-778.

16. Kloehn SJ. Guiding alveolar growth and eruption of teeth to reduce treatment time and produce a more balanced denture and face. Angle Orthod 1947;17:10-33.

17. Barton JJ. High-pull headgear versus cervical traction: a cephalometric comparison. Am J Orthod Dentofacial Orthop 1972;62:517-529.

18. Wieslander L, Buck DL. Physiologic recovery after cervical traction therapy. Am J Orthod Dentofacial Orthop 1974;66:294-301.

19. Cook $A H$, Sellke TA, BeGole EA. Control of the vertical dimension in Class II correction using a cervical headgear and lower utility arch in growing patients. Part I. Am J Orthod Dentofacial Orthop 1994;106:376-388.

20. Haas AJ. Palatal expansion: just the beginning of dentofacial orthopedics. Am J Orthod Dentofacial Orthop 1970;57:219-255.

21. Hubbard GW, Nanda RS, Currier GF. A cephalometric evaluation of nonextraction cervical headgear treatment in Class II malocclusions. Angle Orthod 1994;64:359-70.

22. Schudy FF. The Rotation of the Mandible Resulting from Growth: Its Implications in Orthodontic Treatment. Angle Orthod 1965;35:36-50.

23. Baumrind $\mathrm{S}$, Korn EL, Molthen $\mathrm{R}$, West EE. Changes in facial dimensions associated with the use of forces to retract the maxilla. Am J Orthod Dentofacial Orthop 1981;80:17-30.

24. Joffe $L$, Jacobson A. The maxillary orthopedic splint. Am J Orthod Dentofacial Orthop 1979;75:54-69.

25. Boeck EM, Lunardi N, Pinto AS, Pizzol KEDC, Neto RJB. Occurrence of skeletal malocclusions in Brazilian patients with dentofacial deformities. Braz Dent J 2011; 22:340-345. 